\title{
POTENSI AGENSIA HAYATI DAN NABATI DALAM MENGENDALIKAN PENYAKIT BUSUK RIMPANG JAHE
}

\author{
Loekas Soesanto $^{1}$, Sudarmono ${ }^{1}$, Nur Prihatiningsih ${ }^{1}$, Abdul Manan ${ }^{1}$, \\ Endang Iriani ${ }^{2}$, dan Joko Pramono ${ }^{2}$
}

\begin{abstract}
Potency of biological and botanical agents in controlling ginger rhizome rot. Research aimed at knowing integrity of various control agents in controlling causal agent of ginger rhizome rot. The research was carried out at Gowak Village, Pringsurat District, Temanggung Regency, Central Java Province, from November up to May 2004. Randomized Block Design was used with treatments of biological (Bacillus sp. with density of $\mathrm{x} \times 10^{10} \mathrm{cfu} \mathrm{ml}^{-1}$ suspension and Trichoderma harzianum $20 \mathrm{~g} \mathrm{crop}^{-1}$ ), of botanical (clove leaves powder of $20 \mathrm{~g} \mathrm{crop}^{-1}$ and neem seeds extract of $25 \mathrm{ml} \mathrm{crop}^{-1}$ ), and synthetical agents (benomil with concentration of $2 \mathrm{~g} \mathrm{l}^{-1}$ ) either alone or in combination, with three replicates. Variables observed were incubation period, disease intensity, infection rate, number of leaves per crop, crop height, and ginger production per hectare. Result of the research showed that the location was endemic of the disease. The treatments could generally retard the incubation period and the infection rate, decrease the disease intensity, and increase the ginger production. The highest ginger yield was obtained from the plot given Trichoderma harzianum (Trikonis), either alone or in combination with the dry clove leaves of $10 \mathrm{~g} \mathrm{crop}^{-1}$ as many as four times with interval of seven days started from seedling planted.
\end{abstract}

Key words : clove leaves powder, ginger rhizoma rot, Trichoderma harzianum

\section{PENDAHULUAN}

Jahe merupakan salah satu tanaman tetemuan dari sekitar 140 spesies, yang banyak dikembangkan di berbagai daerah karena banyak kegunaannya, bahkan juga merupakan bahan komoditas ekspor nonmigas andalan (Rukmana, 2000). Di Indonesia, banyak ditanam jahe dari berbagai jenis, terutama jahe gajah, di samping jahe lokal, misalnya jahe merah dan jahe putih kecil, meskipun jahe ini termasuk yang rentan terhadap gangguan organisme pengganggu tamanan (OPT) (DPI Call Centre, 2001; Soesanto et al., 2003).

Banyak kendala dijumpai di pertanaman jahe, salah satunya yang sangat penting, adalah penyakit busuk rimpang yang disebabkan oleh jamur Fusarium oxysporum Schlecht. f.sp. zingiberi Trujillo (Semangun, 1989; 1992; Gonsalves and Ferreira, 1993). Hal ini sesuai dengan hasil penelitian yang telah dilakukan oleh Soesanto et al. (2003), yang menunjukkan bahwa jamur Fusarium oxysporum f.sp. zingiberi merupakan penyebab penyakit busuk rimpang yang dominan pada tanaman jahe.
Berbagai macam pengendalian telah banyak dilakukan terhadap penyakit busuk rimpang jahe, tetapi hasilnya masih belum mantap dan bahkan penyakit makin luas tersebar. Hal ini disebabkan oleh kurangnya pengetahuan tentang berbagai faktor yang mempengaruhi perkembangan penyakit di lapang (Zadoks and Schein, 1979; Campbell, 1986). Penggunaan fungisida masih belum mampu mengatasi masalah ini di lapang (Dalmadi dan Supriono, 1996). Sementara itu, penggunaan cara pengendalian lainnya, seperti agensia hayati dan nabati, belum banyak dilakukan.

Beberapa agensia hayati, seperti T. harzianum ternyata mampu mengendalikan $F$. oxysporum pada kapas dan melon (Sivan and Chet, 1989 dalam Hjeljord and Tronsmo, 1998) dan B. subtilis dapat mengendalikan $F$. oxysporum f.sp. gladioli pada anak subang bunga gladiol (Djatnika, 1997). Bahkan hasil penelitian Amalia (2004) menunjukkan bahwa gabungan antagonis B. subtilis dan P. fluorescens P60 dapat menekan penyakit busuk rimpang jahe in planta. Sementara itu, nimba dan sirih dapat digunakan untuk mengendalikan Fusarium sp. (Simarmata et al., 1994) serta serbuk daun dan bunga

\footnotetext{
1 Jurusan Hama dan Penyakit Tumbuhan, Fakultas Pertanian, Universitas Jenderal Soedirman, Purwokerto

${ }^{2}$ BPTP Jawa Tengah, Ungaran
} 
cengkeh mampu mengendalikan F. oxysporum f.sp. vanillae pada panili (Tombe et al., 1993).

Penelitian mempunyai tujuan untuk mengetahui keterpaduan antar-jenis agensia pengendali dalam menekan penyakit busuk rimpang jahe.

\section{BAHAN DAN METODE}

Lokasi dan waktu penelitian. Penelitian dilaksanakan di sentra produksi jahe di Desa Gowak, Kecamatan Pringsurat, Kabupaten Temanggung, dengan ketinggian tempat $\pm 600 \mathrm{~m}$ dpl. Penelitian berlangsung selama sembilan bulan yang dimulai sejak bulan September 2003 sampai Juni 2004.

Penyiapan bibit jahe varietas Gajah. Bibit jahe varietas Gajah diperoleh dari petani jahe di Kecamatan Ampel, Kabupaten Boyolali. Bibit jahe dipilih yang sehat dan bersih dari kerusakan, kemudian dipotong dengan pisau yang disterilkan dalam larutan natrium hipoklorit 1\%, sehingga setiap potongan bibit mempunyai 2-3 mata tunas.

Penyiapan lahan. Lahan dipilih dari lahan yang biasa ditanami jahe dan sebagai daerah endemi penyakit busuk rimpang. Lahan diolah, dibuat petak ukuran $(2 \times 2) \mathrm{m}$ dengan jarak antar-petak 0,25 m. Selanjutnya petak dibuat lubang tanam dengan jarak tanam $(30 \times 40) \mathrm{cm}$, dan ke dalamnya dimasukkan pupuk kandang matang sebanyak $\pm 0,5 \mathrm{~kg}$. Lahan tersebut siap untuk ditanami bibit jahe.

Penyiapan agensia hayati. Agensia hayati $B$. subtilis dan T. harzianum, diperoleh dari hasil isolasi sampel tanah dari Kabupaten Temanggung, dan yang telah diuji mampu menekan patogen busuk rimpang in vitro dan in planta. Penyiapan B. subtilis pada medium NA dan PDA, diperbanyak pada medium CDL (Tuite, 1969) dan dikocok (Selecta) selama 4 hari pada suhu kamar dengan kecepatan $150 \mathrm{rpm}$. Selanjutnya disaring dan diencerkan sampai kepadatan $\mathrm{x} \times 10^{10}$ upk $\mathrm{ml}^{-1}$ larutan. Agensia T. harzianum disiapkan pada medium PDA, kemudian diperbanyak pada medium campuran dedak, serbuk gergaji, gula, dan dolomit yang telah disterilkan dan diinkubasi selama 30 hari (formula diberi nama Trikonis).

Penyiapan pestisida nabati. Ekstrak biji nimba diperoleh dengan cara merendam 20 g tepung biji nimba dalam satu liter air selama 2-3 hari, lalu disaring (Nursol, 2000). Daun cengkeh dikeringkan dengan oven pada suhu $80^{\circ} \mathrm{C}$ selama 4 hari, kemudian ditumbuk sampai berbentuk serbuk. Dosis serbuk daun cengkeh yang digunakan pada skala lapang adalah 20 g tanaman $^{-1}$ (Tombe et al., 1993).

Penyiapan fungisida kimia sintetis. Fungisida kimia sintetis yang digunakan adalah benomil. Penyiapannya dilakukan di lahan ketika akan digunakan, dengan dosis sesuai anjuran, yaitu $2 \mathrm{~g} \mathrm{l}^{-1}$.

Pemberian perlakuan. Perlakuan yang diberikan dapat dilihat seperti pada Tabel 1.

Peubah dan Pengukuran. Masa inkubasi; intensitas penyakit dengan menggunakan rumus: $\mathrm{IP}=\mathrm{a} / \mathrm{b} \times 100 \%$, IP: intensitas penyakit, a: jumlah tanaman sample yang terserang busuk rimpang, dan b: jumlah tanaman yang diamati tiap lokasi sampel; laju infeksi dengan menggunakan rumus Van der Plank (1963); jumlah daun per tanaman; tinggi tanaman; dan produksi per satuan luas (kg/Ha).

Analisis data. Data dianalisis dengan uji F, apabila berbeda nyata, dilanjutkan dengan uji BNJ pada taraf $5 \%$.

\section{HASIL DAN PEMBAHASAN}

Pengaruh Perlakuan Terhadap Masa Inkubasi. Gejala nampak lebih awal pada tanaman kontrol, baik tanpa maupun yang diinokulasi jamur Fusarium, sedangkan tanaman pada petak perlakuan belum menampakkan gejala penyakit busuk rimpang. Hal ini didukung data intensitas penyakit, yang membuktikan bahwa lahan tersebut adalah lahan endemis penyakit busuk rimpang. Keadaan ini memperkuat hasil penelitian Soesanto et al. (2003), bahwa penyakit layu Fusarium pada tanaman jahe tersebar antara lain di Kabupaten Temanggung.

Pada Tabel 2, nampak bahwa perlakuan T. harzianum (T4 dan T8) mampu memperlambat masa inkubasi (107 hari setelah inokulasi) bahkan gabungan dengan serbuk daun cengkeh dapat lebih lama (114 hari setelah inokulasi), jika dibandingkan dengan perlakuan lain dan kontrol (86-93 hari setelah inokulasi), termasuk yang diperlakukan dengan kimia sintetis dan pestisida nabati secara tunggal.

Hal ini menunjukkan bahwa keberadaan patogen busuk rimpang di dalam tanah dapat dihambat pertumbuhan dan perkembangannya dengan pemberian perlakuan agensia hayati dan pestisida nabati, baik secara tunggal maupun gabungan. Hal ini sesuai dengan pendapat Tombe et al. (1993), Dalmadi 
Tabel 1. Perlakukan yang dilakukan

\begin{tabular}{ccccccc}
\hline Perlakuan & Fusarium & Tricho. & Bacillus & Benomil & Cengkeh & Nimba \\
\hline K1 & - & - & - & - & - & - \\
K2 & + & - & - & - & - & - \\
T1 & + & - & - & + & - & - \\
T2 & + & - & - & - & + & - \\
T3 & + & - & - & - & - & + \\
T4 & + & + & - & - & - & - \\
T5 & + & - & + & - & + & - \\
T6 & + & - & - & + & - & + \\
T7 & + & - & - & + & + & - \\
T8 & + & + & - & - & + & - \\
T9 & + & - & + & - & - & + \\
T10 & + & + & - & - & - & + \\
T11 & + & - & + & - & & + \\
\hline
\end{tabular}

Keterangan: - = tanpa diperlakukan, $+=$ dengan perlakuan: Fusarium $=$ perendaman dengan kepadatan $\mathrm{x} \times 10^{6}$ konidium $\mathrm{ml}^{-1}$ larutan selama 5 menit atau disiram sebanyak $10 \mathrm{ml}$, Bacillus sp. dengan kepadatan $\mathrm{x} \times 10^{10}$ upk ml ${ }^{-1}$ larutan selama 5 menit, benomil = perendaman dosis $2 \mathrm{~g} \mathrm{l}^{-1}$ selama 5 menit, cengkeh $=$ ditabur $20 \mathrm{~g} \mathrm{tanaman}^{-1} 7 \mathrm{kali}$ interval 7 hari, nimba $=\operatorname{siram~} 25 \mathrm{ml} \operatorname{tanaman}^{-1} 7$ atau 4 kali interval 7 hari, Tricho $=$ campur ke tanah $20 \mathrm{~g}_{\text {tanaman }^{-1}}$.

Tabel 2. Pengaruh perlakuan yang diberikan terhadap masa inkubasi dan laju infeksi penyakit busuk rimpang jahe

\begin{tabular}{llcccccc}
\hline Perlakuan & $\begin{array}{l}\text { Masa } \\
\text { inkubasi }\end{array}$ & 1 & \multicolumn{7}{c}{ Laju infeksi (unit/hari) pengamatan ke- } \\
& (hsi) & & 2 & 3 & 4 & 5 & 6 \\
\hline K1 & 86 & $-0,0071$ & $-0,0074$ & $-0,0045$ & $-0,0063$ & $-0,0033$ & $-0,0017$ \\
K2 & 93 & $-0,0059$ & $-0,0019$ & $-0,0060$ & $-0,0046$ & $-0,0037$ & $-0,0046$ \\
T1 & 86 & $-0,0062$ & $-0,0026$ & $-0,0012$ & $-0,0055$ & $-0,0066$ & $-0,0029$ \\
T2 & 86 & $-0,0086$ & $-0,0037$ & $-0,0016$ & $-0,0018$ & $-0,0052$ & $-0,0080$ \\
T3 & 86 & $-0,0054$ & $-0,0053$ & $-0,0029$ & $-0,0030$ & $-0,0091$ & $-0,0064$ \\
T4 & 107 & $-0,0024$ & $-0,0025$ & $-0,0040$ & $-0,0014$ & $-0,0027$ & $-0,0072$ \\
T5 & 93 & $-0,0122$ & $-0,0091$ & $-0,0029$ & $-0,0030$ & $-0,0015$ & $-0,0049$ \\
T6 & 100 & $-0,0023$ & $-0,0013$ & $-0,0011$ & $-0,0067$ & $-0,0037$ & $-0,0070$ \\
T7 & 93 & $-0,0023$ & $-0,0018$ & $-0,0037$ & $-0,0049$ & $-0,0040$ & $-0,0129$ \\
T8 & 114 & $-0,0037$ & $-0,0038$ & $-0,0013$ & $-0,0013$ & $-0,0078$ & $-0,0027$ \\
T9 & 93 & $-0,0059$ & $-0,0023$ & $-0,0052$ & $-0,0013$ & $-0,0079$ & $-0,0084$ \\
T10 & 93 & $-0,0037$ & $-0,0037$ & $-0,0026$ & $-0,0013$ & $-0,0028$ & $-0,0085$ \\
T11 & 93 & $-0,0061$ & $-0,0038$ & $-0,0026$ & $-0,0016$ & $-0,0027$ & $-0,0126$ \\
\hline
\end{tabular}

Keterangan: hsi = hari setelah inokulasi, $\mathrm{K} 1=$ kontrol tanpa inokulasi, $\mathrm{K} 2=$ kontrol dengan inokulasi patogen, $\mathrm{T} 1=$ benomil, $\mathrm{T} 2=$ cengkeh, $\mathrm{T} 3=$ nimba, $\mathrm{T} 4=\mathrm{T}$. harzianum, $\mathrm{T} 5=$ Bacillus sp., $\mathrm{T} 6=$ benomil + cengkeh, $\mathrm{T} 7=$ benomil + nimba, $\mathrm{T} 8=\mathrm{T}$. harzianum + cengkeh, $\mathrm{T} 9=$ Bacillus sp + cengkeh, $\mathrm{T} 10$ $=T$. harzianum + nimba, dan T11 = Bacillus sp. + nimba. 
dan Supriono (1996), dan Sivan and Chet (1989 dalam Hjeljord and Tronsmo, 1998).

Penundaan masa inkubasi khususnya pada tanaman yang diberi Trichoderma sp. karena adanya mekanisme penghambatan, berupa persaingan dengan jamur patogen, baik dalam hal ruang maupun nutrisi. Kondisi ini sesuai dengan pendapat Tronsmo (1996), yang menyatakan bahwa jamur $T$. harzianum mempunyai mekanisme persaingan dan mampu menghasilkan enzim $\beta$-(1-3) glukanase, kitinase, dan enzim lisis. Selain itu, Santoso et al. (1999) menyebutkan bahwa $T$. harzianum menghasilkan antibiotika yang mampu mengurangi pertumbuhan jamur Phytium sp. Bahkan jauh sebelumnya, Cook dan Baker (1983) menyatakan bahwa senyawa gliotoksin dan viridin yang dihasilkan oleh Trichoderma spp. bersifat menghambat patogen tanaman.

Pengaruh Perlakuan Terhadap Intensitas Penyakit. Intensitas penyakit yang diamati menunjukkan peningkatan yang beragam antarperlakuan, yaitu intensitas penyakit lebih tinggi dijumpai pada tanaman kontrol, jika dibandingkan dengan tanaman pada petak perlakuan (Tabel 3.). Hal ini sesuai hasil pengamatan terhadap masa inkubasi. Pada Tabel 2 nampak bahwa intensitas penyakit pada kontrol tanpa inokulasi (K1) menunjukkan data tertinggi (25,54\% pada pengamatan ke-7). Hal ini menandakan bahwa lokasi yang digunakan benarbenar merupakan daerah endemi penyakit busuk rimpang. Pada pengamatan ke-7, intensitas penyakit pada perlakuan T4, T6, T7, T8, T9, dan T10 lebih kecil, yaitu masing-masing 12,67, 12,8, 13,08, 13,46, 14,75 , dan $16,23 \%$ atau lebih rendah $49,61-63,55 \%$ bila dibandingkan dengan kontrol. Kondisi ini menunjukkan bahwa pemberian agensia hayati secara gabungan dengan pestisida nabati mampu menurunkan intensitas penyakit busuk rimpang jahe.

Perlakuan T4 dan T8, atau pemberian antagonis baik secara tunggal maupun digabung dengan pestisida nabati, ternyata mampu menurunkan intensitas penyakit sekitar 50\%. Hal ini sesuai dengan pendapat Agrios (1997), bahwa pemanfaatan Trichoderma sp. telah terbukti menghambat beberapa jamur tular-tanah, antara lain Fusarium. Hasil penelitian Koch (1999) membuktikan bahwa jamur T. harzianum mampu mengendalikan jamur patogen tular-tanah Rhizoctonia solani dan Pythium ultimum. Bahkan jamur T. harzianum juga mampu mengendalikan patogen layu Verticillium dahliae pada kentang (Ordentlich et al., 1990) dan Sclerotium rolfsii pada kacang tanah (Backman and RodriguezKabana, 1975 dalam Adams, 1990). Rao (1992) mengemukakan bahwa Trichoderma sp. merupakan jamur tanah yang banyak ditemukan di permukaan akar atau bagian lain dari berbagai jenis tanaman. Domsch et al. (1993) menambahkan bahwa jamur antagonis ini umumnya dijumpai di daerah yang relatif hangat dan bahkan sampai ketinggian $3.450 \mathrm{~m}$ dpl. Penggabungan jamur antagonis T. harzianum serbuk daun cengkeh mampu mengendalikan F. oxysporum f.sp. zingiberi. Hal ini membuktikan bahwa serbuk daun cengkeh juga dapat mengendalikan patogen tular-tanah (Tombe et al., 1993).

Perlakuan dengan kimia sintesis, yaitu benomil (T1), masih belum mampu mengendalikan penyakit busuk rimpang bila dibandingkan dengan agensia hayati. Hal ini disebabkan fungisida diduga belum mampu mencapai propagul jamur patogen di dalam tanah, di samping dapat menyebabkan patogen menjadi tahan dan munculnya ras baru, serta terbunuhnya mikroba tanah lainnya. Perlakuan serbuk daun cengkeh (T2) atau ekstrak biji nimba (T3) secara tunggal mampu menekan perkembangan penyakit, meskipun masih rendah bila dibandingkan dengan serbuk daun cengkeh yang digabung dengan Trikonis (T8). Hal ini juga nampak pada perlakuan Bacillus sp. secara tunggal (T5). Keadaan ini diduga disebabkan oleh terbunuhnya mikroba berguna lain di dalam tanah karena pestisida nabati. Juga Bacillus sp. secara tunggal belum mampu beradaptasi dengan lingkungan baru dan kalah bersaing dengan jamur patogennya. Selain itu, adanya curah hujan yang cukup tinggi selama tanam berperan penting dalam penyebaran bakteri ke daerah lain, sehingga tidak mampu melindungi perakaran tanaman dari serangan patogen Fusarium. Hal ini sesuai dengan pendapat Parke et al. (1986 dalam Handelsman and Stabb, 1996).

Pengaruh Perlakuan Terhadap Laju Infeksi. Perlakuan gabungan antara T. harzianum dan nimba mampu memperlambat laju infeksi, yaitu dari 0,0037 unit/hari menjadi -0,0085 unit/hari. Selain itu, perlakuan agensia hayati lain, yaitu Bacillus sp., yang digabung dengan pestisida nabati juga mampu memperlambat laju infeksi, misalnya pada perlakuan T9 dan T11 (Tabel 2). Hasil pengamatan terhadap laju infeksi penyakit busuk rimpang pada tanaman jahe ini sesuai dengan hasil pengamatan intensitas penyakit, yaitu perlakuan agensia hayati baik secara tunggal maupun gabungan dengan pestisida nabati 
Tabel 3. Pengaruh perlakuan yang diberikan terhadap rerata intensitas penyakit penyakit busuk rimpang jahe

\begin{tabular}{llllllll}
\hline Perlakuan & \multicolumn{7}{c}{ Intensitas penyakit (\%) pengamatan ke- } \\
& 1 & \multicolumn{1}{c}{2} & \multicolumn{1}{c}{3} & \multicolumn{1}{c}{4} & \multicolumn{1}{c}{5} & 6 & 7 \\
\hline K1 & 7,80 & 12,45 & 16,87 & 19,44 & 22,90 & 24,67 & 25,54 \\
K2 & 6,30 & 10,24 & 11,17 & 14,83 & 17,56 & 19,67 & 20,34 \\
T1 & 0,85 & 5,08 & 6,82 & 7,61 & 11,11 & 15,14 & 16,08 \\
T2 & 0,79 & 6,59 & 8,97 & 10,01 & 10,81 & 13,98 & 15,02 \\
T3 & 3,46 & 7,04 & 10,45 & 12,25 & 14,06 & 19,38 & 20,30 \\
T4 & 3,33 & 5,00 & 6,66 & 9,27 & 10,14 & 11,81 & 12,67 \\
T5 & 0,87 & 9,01 & 14,65 & 16,38 & 18,11 & 18,99 & 19,87 \\
T6 & 0,00 & 1,62 & 2,52 & 3,33 & 7,75 & 10,13 & 12,67 \\
T7 & 0,00 & 1,60 & 2,41 & 4,94 & 8,17 & 10,70 & 13,08 \\
T8 & 0,00 & 2,56 & 5,12 & 5,98 & 6,83 & 11,79 & 13,46 \\
T9 & 0,00 & 4,04 & 5,57 & 8,94 & 9,75 & 14,63 & 14,75 \\
T10 & 5,63 & 8,07 & 10,47 & 12,12 & 12,94 & 15,40 & 16,23 \\
T11 & 5,74 & 9,70 & 12,08 & 13,67 & 14,65 & 16,24 & 17,24 \\
\hline
\end{tabular}

Keterangan: $\mathrm{K} 1=$ kontrol tanpa inokulasi, $\mathrm{K} 2=$ kontrol dengan inokulasi patogen, $\mathrm{T} 1=$ benomil, $\mathrm{T} 2=$ cengkeh, T3 = nimba, T4 = T. harzianum, T5 = Bacillus sp., T6 = benomil + cengkeh, $\mathrm{T} 7=$ benomil + nimba, $\mathrm{T} 8=T$. harzianum + cengkeh, $\mathrm{T} 9=$ Bacillus sp. + cengkeh, $\mathrm{T} 10=T$. harzianum + nimba, dan T11 = Bacillus sp. + nimba.

berpengaruh positif terhadap keberadaan penyakit busuk rimpang jahe.

Pengaruh Perlakuan Terhadap Komponen

Pertumbuhan. Dari Tabel 4. nampak bahwa jumlah daun per batang semu tanaman jahe tidak berbeda nyata antar-perlakuan. Sementara itu, jumlah daun per batang semu tanaman jahe pada petak perlakuan lainnya tidak berbeda nyata dengan jumlah daun per batang semu tanaman pada petak kontrol. Hal ini berarti perlakuan tidak berpengaruh terhadap jumlah daun tanaman jahe.

Pengaruh Perlakuan Terhadap Produksi. Tanaman jahe yang tidak diberi perlakuan dengan agansia apapun memperlihatkan hasil paling sedikit, karena daerah penanaman jahe merupakan daerah endemi penyakit busuk rimpang, yang dapat menurunkan hasil panen. Perlakuan pelet Trichoderma (Trikonis) memberikan hasil panen tertinggi bila dibandingkan dengan perlakuan lain. Sementara itu, perlakuan kimia dengan fungisida benomil, agensia hayati Bacillus sp., serta pestisida nabati daun cengkah maupun nimba, tidak menunjukkan perbedaan, tetapi masih jauh lebih baik bila dibandingkan dengan kontrol. Sementara itu, nampak pada Tabel 4 bahwa perlakuan T4 dan T8 mampu meningkatkan hasil panen jahe hampir 2 lipat, yang meningkat sekitar $50 \%$ bila dibandingkan dengan kontrol. Hal ini seturut dengan hasil penelitian
Ordentlich et al. (1990), yang membuktikan bahwa penggunaan $T$. harzianum mampu meningkatkan produksi kentang sampai 38,5\%.

Selain itu, gabungan agensia pengendali baik antar-nabati (T6), nabati dan kimia (T7) maupun nabati dan hayati (T8, T9, T10, dan T11), juga mampu meningkatkan produksi jahe. Hal ini diduga adanya pengaruh sinergis dari kedua agensia pengendali tersebut, sehingga memberikan pengaruh positif terhadap tanaman. Gabungan T. harzianum dan fungisida captan mampu mengurangi pengkolonian $V$. dahliae secara nyata lebih baik, dan meningkatkan produksi kentang sampai $84 \%$ bila dibandingkan penerapan secara tunggal yang hanya meningkat sebesar 38,5\% (Ordentlich et al., 1990). Didukung pula oleh hasil penelitian Fuchs and Defago (1991), Lemanceau and Alabouvette (1991), Matsani (2000), dan Soesanto (2000).

\section{SIMPULAN}

Lokasi penelitian di Kabupaten Temanggung, tepatnya di Desa Gowak, Kecamatan Pringsurat, merupakan daerah endemis penyakit busuk rimpang jahe. Penyakit busuk rimpang jahe di lahan dapat dikendalikan dengan penerapan agensia hayati

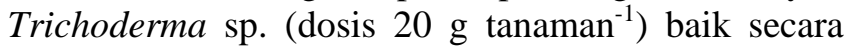


Tabel 4. Rerata jumlah daun per batang semu, selisih tinggi tanaman, dan produksi jahe akibat perlakuan

\begin{tabular}{|c|c|c|c|c|c|}
\hline \multirow[t]{2}{*}{ Perlakuan } & \multicolumn{3}{|c|}{ Jumlah daun pengamatan ke- } & \multirow{2}{*}{$\begin{array}{l}\text { Selisih tinggi } \\
\text { tanaman }(\mathrm{cm})\end{array}$} & \multirow{2}{*}{$\begin{array}{c}\text { Produksi } \\
\text { (kg/ha) }\end{array}$} \\
\hline & 1 & 2 & 3 & & \\
\hline K1 & 5 & 7 & 8 & 70,73 bcd & $39.958,33 \mathrm{~d}$ \\
\hline K2 & 5 & 7 & 8 & 68,87 bcd & $40.583,33 \mathrm{~cd}$ \\
\hline $\mathrm{T} 1$ & 5 & 7 & 8 & $64,40 \mathrm{~cd}$ & $48.666,67 \mathrm{~cd}$ \\
\hline $\mathrm{T} 2$ & 4 & 6 & 7 & 70,47 bcd & $50.916,67$ bcd \\
\hline T3 & 5 & 7 & 8 & $75,90 \mathrm{ab}$ & 50.833,33 abcd \\
\hline $\mathrm{T} 4$ & 5 & 7 & 8 & 81,20 a & $69.958,33$ a \\
\hline T5 & 5 & 7 & 7 & $63,80 \mathrm{~cd}$ & $51.250,00$ abcd \\
\hline T6 & 6 & 6 & 8 & $66,60 \mathrm{bcd}$ & $61.375,00 \mathrm{abc}$ \\
\hline $\mathrm{T} 7$ & 5 & 7 & 9 & $61,90 \mathrm{~d}$ & 61.791,67 abc \\
\hline T8 & 4 & 6 & 7 & $66,07 \mathrm{bcd}$ & $69.416,67 \mathrm{ab}$ \\
\hline T9 & 5 & 7 & 9 & 72,97 abc & 52.833,33 bcd \\
\hline $\mathrm{T} 10$ & 4 & 6 & 7 & 68,67 bcd & $57.000,00 \mathrm{abcd}$ \\
\hline $\mathrm{T} 11$ & 6 & 8 & 9 & 67,20 bcd & 56.500,00 abcd \\
\hline
\end{tabular}

Keterangan: Angka yang diikuti oleh huruf yang sama pada kolom yang sama menunjukkan tidak berbeda nyata menurut DMRT pada tingkat kesalahan 5\%.

tunggal maupun digabung dengan serbuk daun cengkeh (dosis $10 \mathrm{~g}^{\text {tanaman }^{-1} 4}$ kali interval 7 hari sekali), yang diberikan sejak bibit mulai ditanam, dan ditaburkan di sekitar pertanaman.

\section{SANWACANA}

Penelitian ini didanai dari Proyek ARMP-II melalui BPTP Jawa Tengah, untuk itu diucapkan terima kasih. Terima kasih juga disampaikan kepada sdr. Bonifatius Yogie T. atas bantuannya selama penelitian berlangsung.

\section{DAFTAR PUSTAKA}

Adams, P.B. 1990. The potential of mycoparasites for biological control of plant diseases. Annu. Rev. Phytopathol. 28:59-72.

Agrios, G.N. 1997. Plant Pathology, $4^{\text {th }}$ ed. Academic Press, San Diego.

Amalia, R. 2004. Potensi Beberapa Anatagonis dalam Menekan Fusarium oxysporum Schlecht. f.sp. zingiberi Trujillo in vitro dan in planta. Skripsi. Fakultas Pertanian, Universitas Jenderal Soedirman, Purwokerto. (Tidak dipublikasikan).
Campbell, C.L. 1986. Interpretation and uses of disease progress curves for root diseases. Pp. 38-54. In: K.J. Leonard and W.E. Fry (Eds.), Plant Disease Epidemiology, Population Dynamics and Management, Vol. 1. MacMillan Publ. Co., New York.

Cook, R.J. dan H.K. Baker. 1983. The Nature and Practise of Biological Control of Plant Pathogens. APS, St. Paul, Minnesota.

Dalmadi dan Supriono. 1996. Penyakit Tanaman Kenaf dan Pengendaliannya. Monograf Balitas, Malang.

Djatnika, I. 1997. Pengaruh Bacillus subtilis terhadap intensitas penyakit layu Fusarium gladiol. Prosiding Kongres XIV dan Seminar Nasional PFI Palembang.

Domsch, K.H., W. Gams, and T-H. Anderson. 1993. Compendium of Soil Fungi, vol. 1. IHW-Verlag, Eching.

DPI Call Centre. 2001. Ginger in Queensland: Commercial Production. (On-line) http://www.dpi.qld.gov.au/horticulture/4748.ht

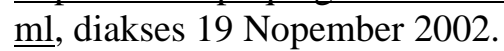


Fuchs, J. and G. Defago, 1991. Protection of tomatoes against Fusarium oxysporum f.sp. lycopersici by combining a non-pathogenic Fusarium with different bacteria in untreated soil. Pp. 51-56. In: C. Keel, B. Koller, and G. Defago (Eds.), Plant Growth Promoting Rhizobacteria. Interlaken, Switzerland.

Gonsalves, A.K. and S.A. Ferreira. 1993. Fusarium Primer. ( On-line ). http: // www. extento. hawaii.edu/kbase/crop/Type/f_oxys.htm,diakses 21 Oktober 2002.

Handelsman, J. and E.V. Stabb. 1996. Biocontrol of soilborne plant pathogens. The Plant Cell 8:1855-1869.

Hjeljord, L. and A. Tronsmo, 1998. Trichoderma and Gliocladium in biological control: an overview. Pp. 131-152. In: G.E. Harman and C.P. Kubicek (Eds.), Trichoderma and Gliocladium Vol. 2. Taylor \& Francis Ltd., London.

Koch, E. 1999. Evaluation of commercial products for microbial control of soil-borne plant diseases. Crop Protection 18:1190125.

Lemanceau, P. and C. Alabouvette. 1991. Biological control of Fusarium diseases by the association of fluorescent Pseudomonas and nonpathogenic Fusarium. Pp. 45-50. In. C. Keel, B. Keller, and G. Defago (Eds.), Plant Growth promoting Rhizobacteria. Interlaken, Switzerland.

Matsani, M.A. 2000. Efektivitas Kombinasi Dua Antagonis Terhadap Penekanan Penyakit Layu Sclerotium Pada Kedelai. Skripsi. Fakultas Pertanian, Unsoed, Purwokerto. (Tidak dipublikasikan).

Nursol, M. 2000. Pembuatan Pestisida Nabati Secara Sederhana dan Aplikasinya Di Lapangan. Pelatihan Perbanyakan Agensia Hayati Bagi Petugas Penelitian, BPTP Medan, 13-15 Maret, Medan.

Ordentlich A., A. Nachmias, and I. Chet. 1990. Integrated control of Verticillium dahliae in potato by Trichoderma harzianum and captan. Crop Protection 9:363-366.
Rao, N.S. 1992. Mikroorganisme Tanah dan Pertumbuhan Tanaman. Edisi kedua. Diterjemahkan oleh H. Susilo, 1994. UI Press, Jakarta.

Rukmana, R. 2000. Usaha Tani Jahe. Kanisius, Yogyakarta.

Santoso, E., M. Turjaman, dan S.T. Nuhamara. 1999. Studi Antagonisme T. harzianum Rifai Terhadap Pythium sp. Penyebab Penyakit Lodoh pada Semai Sengon (Paraserianthes falctaria (L.) Nielsen). Prosiding dan Seminar IV PFI, Surakarta. Hal. 553-559.

Semangun, H. 1989. Penyakit-penyakit Tanaman Hortikultura di Indonesia. Gadjah Mada University Press, Yogyakarta. Hal. 222-228.

Semangun, H. 1992. Host Index of Plant Diseases in Indonesia. Gadjah Mada University Press, Yogyakarta.

Simarmata, R.U., I.N. Andayani, E. Sulistiati, Haryani, dan Soelaksono. 1994. Pedoman Pengenalan Pestisida Botani. Direktorat Bina Perlindungan Tanaman Perkebunan, Departemen Pertanian, Jakarta.

Soesanto, L. 2000. Ecology and Biological Control of Verticillium dahliae. Ph.D. Thesis. University of Wageningen, Wageningen, the Netherlands.

Soesanto, L., Soedharmono, N. Prihatiningsih, A. Manan, E. Iriani, dan J. Pramono. 2003. Penyakit busuk rimpang jahe di sentra produksi jahe Jawa Tengah: 1 . Identifikasi dan sebaran. Tropika 11(2):178-185.

Tombe, M., A. Nurawan, dan Sukamto. 1993. Penelitian Penggunaan Daun Cengkeh Dalam Pengendalian Penyakit Busuk Batang Panili. Prosiding Seminar Hasil penelitian dalam Rangka Pemanfaatan Pestisida Nabati, 1-2 Desember, Bogor. Hal. 28-36.

Tombe, M. 1999. Pengenalan dan Perananan Fungisida Nabati Dalam Pengendalian Penyakit Tanaman. Pemanfaatan Pestisida Nabati. Perkembangan Teknologi Tanaman Rempah dan Obat 9(2):16-23. 
Tronsmo, A. 1996. Trichoderma harzianum in Biological Control of Fungal Diseases. Pp. 212221. In: R. Hall (Ed.), Principles and Practise of Managing Soilborne Plant Pathogens. APS Press, St. Paul. Minnesota.

Tuite, J. 1969. Plant Pathological Methods: Fungi and Bacteria. Burgess Publishing Company, Minneapolis.
Van der Plank, J.E. 1963. Plant Disease: Epidemics and Control. Academic Press, New York.

Zadoks, J.C. and R.D. Schein. 1979. Epidemiology and Plant Disease Management, Oxford University Press, Oxford. 
